\title{
Monoclonal Antibody
}

National Cancer Institute

\section{Source}

National Cancer Institute. Monoclonal Antibody. NCI Thesaurus. Code C20401.

An antibody produced by a clone or genetically homogenous fast-growing cells i.e.,

hybridoma. Hybridoma cells are cloned to establish cell lines producing a specific antibody

that is chemically and immunologically homogeneous. They are widely used in cancer detection, diagnosis, and treatment. 